\title{
EXPRESSION OF MUC2 GLYCOPROTEIN ANTIBODY AND VASCULAR ENDOTHELIAL GROWTH FACTOR IN BARRETT'S MUCOSA
}

\author{
Melanija Ražov Radas \\ Division of Gastroenterology, Department of Internal Medicine, Zadar General Hospital, Zadar, Croatia
}

\begin{abstract}
SUMMARY - Higher expression of the mucin 2 (MUC2) glycoprotein and vascular endothelial growth factor (VEGF) in Barrett's mucosa may be associated with a higher risk of esophageal adenocarcinoma development. Thirty-six patients diagnosed with Barrett's esophagus (BE), short-segment, were included in the study due to unsuccessful treatment with proton pump inhibitors. The diagnosis was confirmed by histopathologic analysis of the tissue obtained by esophagogastric junction biopsy. Expression of MUC2 and VEGF was determined by immunohistochemistry. We found four patients in early stage of adenocarcinoma and 32 patients with $\mathrm{BE}$; five of them had indication for argon plasma coagulation treatment, one for radiofrequency ablation and one for endoscopic mucosal resection; 25 patients were treated with proton pump inhibitors. Regression of BE occurred in 25 (69.44\%) patients. MUC2 positivity is unique for goblet cells in patients with $\mathrm{BE}$, but it is not the only marker. VEGF is an indicator of angiogenesis in the mucosa of patients with BE and adenocarcinoma.
\end{abstract}

Key words: Barrett esophagus; Mucin 2; Vascular endothelial growth factor; Proton pump inhibitors; Goblet cells

\section{Introduction}

The nature of Barrett's esophagus (BE) (Fig. 1), progression and rate of progression to malignant disease has not yet been fully explored, and for now, there are no biochemical-immunohistochemical-histopathologic markers that are highly specific for the diagnosis of this disease ${ }^{1,2}$. BE was twenty times less frequently diagnosed in patients than on autopsy ${ }^{1-3}$. Evolution of BE to cancer takes 20 to 30 years $^{1,3}$. A study by Garud et al. ${ }^{4}$ demonstrated the prevalence of $\mathrm{BE}$ to range from $0.9 \%$ to $4.5 \%$, with progression to adenocarcinoma (AC) in $0.5 \%$ per patient per year. Helicobacter pylori $(H$. pylori) positive patients have milder forms of gastroesophageal reflux disease (GERD), BE and lower esophageal stricture compared to those that are $H$. pylori negative ${ }^{5}$. Over the past 20 years, the inci-

Correspondence to: Melanija Ražov Radas, MD, B. Peričića 5, HR23000 Zadar, Croatia

E-mail: melanijarr@gmail.com

Received April 3, 2017, accepted May 5, 2017 dence of esophageal and esophagogastric junction AC was higher than the incidence of any other cancer in the human population ${ }^{3}$.

Mucin 2 (MUC2), a mucin family glycoprotein, has been located in the cytoplasm of goblet cells including small intestine, colon, bronchus, salivary gland, conjunctiva of the eye, but not in normal gastric mucosa. In the context of the study of malignant diseases, MUC2 positive finding was recorded in primary gastrointestinal tumors of the colon, stomach and esophagus; goblet cells in the tissue of metastatic colorectal cancer in the ovary, but not in primary ovarian mucinous $\mathrm{AC}$; and intestinal metaplasia of the esophagus (BE), where expression of MUC2 is shown in goblet cells $^{6-10}$. Accordingly, the questions are: is MUC2 antibody a predictive marker for $\mathrm{BE}$ regression in patients treated with proton pump inhibitors (PPIs), argon plasma coagulation (APC) and/or combination therapy; is its presence associated with progression to dysplasia; and is there expression of the same gene in patients with $\mathrm{AC}$ of the esophagus? 


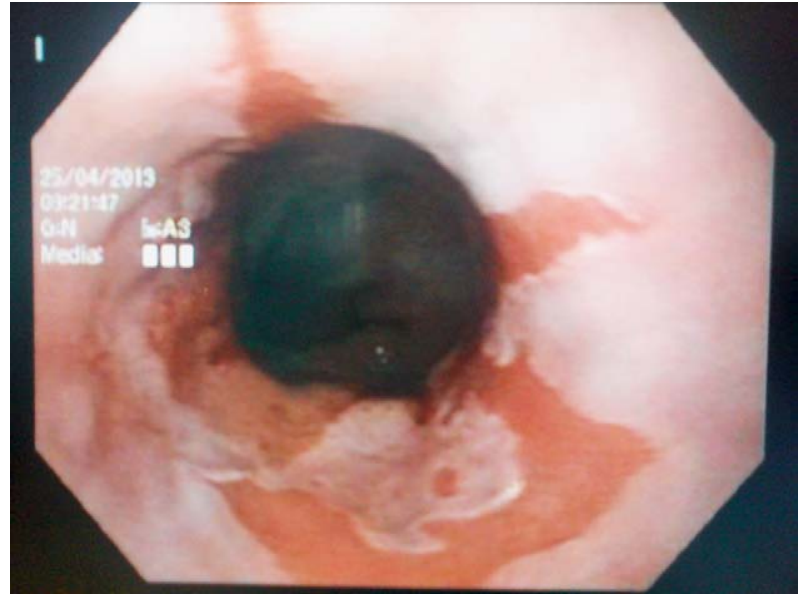

Fig. 1. Endoscopic view of affected esophagogastric mucosa.

Vascular endothelial growth factor (VEGF) is a signaling protein involved in the process of vasculogenesis and angiogenesis. When a cell lacks oxygen, it produces hypoxia inducible factor (HIF), which stimulates the release of VEGF and its binding to the receptor tyrosine kinase, as a precondition for angiogenesis $^{11-14}$. Expression of VEGF was shown to be an important factor in creating a vascular network of tumor growth and metastasis in various and numerous tumors that occur in the human population, such as breast, liver, colon, gastric $\mathrm{AC}$ and squamous cell carcinoma of the esophagus ${ }^{14}$. Endocrine cells with metaplastic altered mucosa showed expression of VEGF in the cytoplasm ${ }^{11}$.

The aim of this study was to examine the expression of MUC2 and VEGF in patients with proven BE.

\section{Patients and Methods}

\section{Study group}

Thirty-six patients with BE treated with PPIs were included in the study. Patients were collected during a period of more than 6 years. In addition to standard procedure (history, physical examination, abdominal ultrasound, basic laboratory findings), esophagogastroduodenoscopy (EGDS) with biopsy of esophagogastric junction was performed in all patients. During a follow up period of 3-6 years, they underwent regular annual endoscopy with biopsies.

This clinical trial enrolled 36 patients aged 18-80 years with GERD and proven existence of $\mathrm{BE}$ or $\mathrm{AC}$.

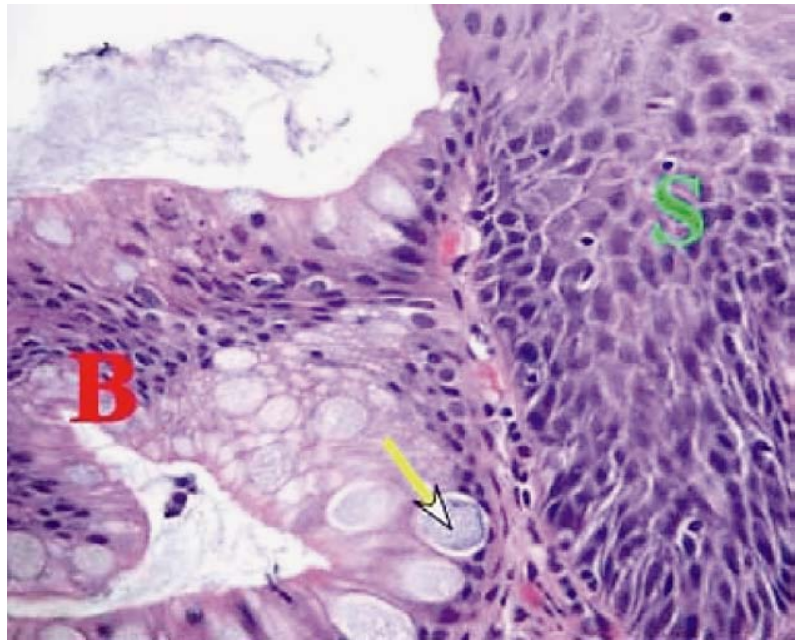

Fig. 2. The $S$ area shows how the squamous cells that line the esophagus appear under the microscope, whereas $B$ area shows Barrett's metaplasia; the arrow points to goblet cells characteristic of Barrett's metaplasia.

All patients were treated at Department of Gastroenterology, Zadar General Hospital from Zadar, Croatia. Control group consisted of the same subjects treated after proven $\mathrm{BE}$ diagnosis that underwent repeat protocol examinations following appropriate therapy according to the guidelines. Inclusion criteria: subjects of both sexes aged $18-80$ years with no previously known malignancy; respondents with positive reflux symptoms; respondents not using anticoagulant therapy; and existence of esophagogastric junction changes in terms of $\mathrm{BE}$ or AC. Exclusion criteria: patients aged $<18$ or $>80$ years; history of malignant disease; patients already treated with a PPI for GERD and without previously made EGDS; subjects on anticoagulant therapy; and subjects that did not understand the questionnaire.

\section{Methods}

The study involved subjects in which the histopathologic analysis verified the existence of BE (Fig. 2) or $\mathrm{AC}$, and the same subjects after $\mathrm{BE}$ treatment with PPI and/or APC, radiofrequency ablation (RFA), endoscopic mucosal resection (EMR), or after esophagectomy. Patients filled out a questionnaire about GERD. Histopathologic analysis included immunohistochemistry of MUC2 and VEGF. Multisystemimmunohistochemical analysis was performed at the Department of Pathology and Forensic Medicine, $\mathrm{Za}$ - 
dar General Hospital, on a DAKO Whale device (DAKO, Santa Clara, USA) with antibodies from the same manufacturer, as follows: first kit EnVision FLEX HIGH pH, MO A-Hu MUC2, clone CCP58 and VEGF Clone: VG1, Isotype: IgG1 kappa; second kitMO-HU Vascular Endothelial Growth Factor.

All patients signed an informed consent and the study was conducted in accordance with ethical principles of the Helsinki Declaration.

\section{Immunohistochemistry of MUC 2 and VEGF}

At the Laboratory of Immunohistochemistry, Department of Pathology, Cytology and Forensic Medicine, Zadar General Hospital, 3-4 $\mu \mathrm{m}$ thick preparations were cut from paraffin blocks of the tumor tissue and then mounted on silanized slides. After cutting, they were heated in a thermostat at $60{ }^{\circ} \mathrm{C}$ for one hour and then stained by applying indirect immunochemistry without biotin using ULTRAVIEW Universal DAB Detection Kit, Ventana brand. Further procedures required for immunohistochemical analysis were performed on a fully automated Ventana BenchmarkGX platform. The MUC2 colon tissue was used as positive control. Findings were interpreted as follows: 0 , no cell staining; 1 , at least $30 \%$ of staining cells; 2 , $31 \%-60 \%$ of staining cells; and $3,>60 \%$ of staining cells.

Tonsil tissue was used as positive control for VEGF. Findings were interpreted as follows: samples stained with anti-VEGF-antibody like yellow-brown granules in the cytoplasm of the cells or plasma membrane. Negative sample had 0-30\% of cells with VEGF, and positive sample had $31 \%-100 \%$ of staining cells.

\section{Statistical analysis}

The results were described as parameters of descriptive statistics using one-way analysis of variance (ANOVA), Mann-Whitney test and $\chi^{2}$-test. The level of significance was set at $\mathrm{p}<0.05$. Data were processed using the Statistica 13.0 software.

\section{Results}

We identified four patients in early stage of $\mathrm{AC}$ and 32 patients with BE (Table 1); five of them had indication for APC treatment (including criteria for APC such as intestinal metaplasia or no dysplasia or
Table 1. Distribution of patients according to diagnosis

\begin{tabular}{|l|l|l|}
\hline \multirow{2}{*}{ Clinical diagnosis } & $1^{\text {st }}$ examination & $2^{\text {nd }}$ examination \\
\cline { 2 - 3 } & $\mathrm{n}(\%)$ & $\mathrm{n}(\%)$ \\
\hline GERD & 0 & $25(69.445 \%)$ \\
Barrett's esophagus & $32(88.89 \%)$ & $7(19.445 \%)$ \\
Carcinoma & $4(11.11 \%)$ & 0 \\
Operated & 0 & $4(11.11 \%)$ \\
Total & $36(100 \%)$ & $36(100 \%)$ \\
\hline
\end{tabular}

GERD = gastroesophageal reflux disease

low-grade dysplasia), and one for RFA and EMR each. Twenty-five patients were treated with PPIs. Regression of BE occurred in 25 (69.44\%) patients. We noted an interesting phenomenon that higher expression of MUC2 was inversely proportionate to VEGF in seven patients (all with carcinoma and three with BE). After all treatment modalities, patients reported reduction or complete disappearance of regurgitation, burning sensation and dyspepsia. Our patients mostly had lowrisk $\mathrm{BE}$, and two patients with high-risk $\mathrm{BE}$ had positive findings of MUC2, VEGF, dysplasia and metaplasia; they were treated with more aggressive treatment methods such as RFA and EMR.

In patients with only mucosal changes in terms of intestinal metaplasia, after APC treatment we found regression of these changes, and endoscopic findings and biopsy confirmed only GERD or healthy oral mucosa. In patients with mucosal changes in terms of intestinal metaplasia and dysplasia of mild to moderate degree, there was no significant regression of symptoms, and regression was of short duration (maximum one year).

In the period between first and second examination, significant changes were recorded in VEGF $\left(\chi^{2}=4.65, \mathrm{df}=1 ; \mathrm{p}=0.031\right)$. Therapy administered between the first and second examination significantly influenced VEGF reduction in BE patients (precisely, reduced it to 0 ), but there was no significant effect on MUC2 reduction.

Immunohistochemistry results coincided with statistics, i.e. there was no causative relationship of positive MUC2 and VEGF findings with a higher degree of dysplasia and/or metaplasia, nor they were associated with a higher incidence of $H$. pylori positive findings, but clearly indicated the existence of intestinal metaplasia and/or dysplasia. 
Fisher exact test was significant $(\mathrm{p}=0.017)$, which means that patients with $\mathrm{AC}$ and those with $\mathrm{BE}$ could be distinguished based on the $H$. pylori expression on esophageal mucosa, i.e. $H$. pylori expression would be lower in AC patients. As already mentioned, this finding should be interpreted with caution because we had only four patients with AC.

\section{Discussion}

Expression of MUC2 is characteristic of goblet cells, which also are a unique but not the only histopathologic marker of BE. Unaffected mucosa has no goblet cells and is not positive for MUC2 ${ }^{15}$. Research has confirmed that the existence of VEGF is not specific to metaplasia of stratified squamous epithelium in the single cylinder, which is another characteristic histopathologic finding in $\mathrm{BE}$. We found changes of mucous membranes with intestinal metaplasia, dysplasia, and new vascular network in the tissue affected with neoplastic alterations.

Since all subjects were administered PPIs with additional endoscopic interventions in those with histologically aggressive disease, it is concluded that the mentioned therapy with PPIs had significant effect on the reduction of VEGF between the two examinations, but had no significant effect on reducing MUC2, which was negative after ablative techniques such as RFA and EMR ${ }^{16}$.

Study results revealed that MUC2 could not distinguish subjects with $\mathrm{AC}$ and those with $\mathrm{BE}$. The reason is that goblet cells were found in both $\mathrm{BE}$ and $\mathrm{AC}^{17}$. Patients with $\mathrm{AC}$ and those with $\mathrm{BE}$ could not be distinguished by VEGF either. This could be explained by the fact that the presence of VEGF was found in both $\mathrm{BE}$ and $\mathrm{AC}^{18}$. Couvelard et al. ${ }^{18}$ demonstrated that VEGF expression correlated with vascularization, but had no independent prognostic value. Our sample of only four patients certainly was too small to make any definite conclusion on non significance of MUC2 and VEGF expression. We need to examine a larger number of patients in future studies.

Immunohistochemical results coincided with statistics, i.e. positive MUC2 and VEGF findings were not causally related to a higher degree of dysplasia and/or intestinal metaplasia, and were not associated with greater incidence of $H$. pylori positive findings but clearly pointed to the existence of intestinal metaplasia and/or dysplasia. Intestinal metaplasia can develop wherever there is squamous epithelium, and transition to dysplasia is the last step in the development of cancer. In the study by Garud et al., the prevalence of $\mathrm{BE}$ ranged from $0.9 \%$ to $4.5 \%$, with progression to $\mathrm{AC}$ in $0.5 \%$ per patient per year ${ }^{4}$.

Expression of $H$. pylori differed significantly between $\mathrm{AC}$ and $\mathrm{BE}$ patients ( $\mathrm{p}=0.017)$, which means that patients with $\mathrm{BE}$ could be distinguished from those with $\mathrm{AC}$ based on the expression of the bacterium on esophageal mucosa, which was lower in the latter. This finding should be interpreted with caution because we had only four patients with AC. This thesis should also be confirmed in future works on a much larger number of patients. Similar results have been reported by Sharma et al., that the presence of $H$. $p y$ lori in gastric mucosa has a protective activity on the esophagogastric junction in $\mathrm{BE}^{19}$.

Mucin expression in progressive stages of chronic gastritis and gastric epithelial infection with $H$. pylori provides identification of intestinal metaplasia, which is characterized by reduced expression of gastric mucins (MUC5AC and MUC6) and de novo expression of $\mathrm{MUC2}^{20}$. MUC2 is a reliable indicator of intestinal metaplasia, which occurs in $H$. pylori infected patients with chronic gastritis ${ }^{20}$. Whether it means protection of gastric mucosa from $\mathrm{AC}$, remains as an idea to be tackled in future work. Therefore, the statistical result according to which AC patients have lower $H$. pylori expression must be taken as an indication that we need to check in future research.

In conclusion, MUC2 positivity is unique in goblet cells in patients with $\mathrm{BE}$, but it is not the only marker. VEGF is an indicator of angiogenesis in the mucosa of patients with $\mathrm{BE}$ with or without intestinal metaplasia and dysplasia, and in patients with AC. The study of MUC2 and VEGF in cells with a high degree of dysplasia and $\mathrm{AC}$ of the esophagus in the general population remains a subject for future research. A specific biomarker for detection of $\mathrm{BE}$ is yet to be discovered.

\section{References}

1. Pulanić R. Gastroezofagealna refluksna bolest. In: Vucelić B, editor. Gastroenterologija i hepatologija. Zagreb: Medicinska naklada, 2002; p. 395-408. (in Croatian)

2. Ljubičić N, Pavić T. Od bolesti gastroezofagealnog refluksa do adenokarcinoma jednjaka: molekularna osnova. In: Pulanić R, 
et al., editors. Algoritmi u gastrointestinalnoj endoskopiji i endoskopskom ultrazvuku. Od gastroezofagealne refluksne bolesti do adenokrcinoma jednjaka - dijagnostičko-terapijski pristupi. Zagreb: Medicinska naklada, 2012; p. 35-50. (in Croatian)

3. Sleisenger and Fordtran's gastroesophageal reflux disease and its complications. In: Feldman M, Friedman LS, Brandt LJ, editors. Sleisenger and Fordtran's Gastrointestinal and Liver Disease, $8^{\text {th }}$ edn. Philadelphia: Saunders, 2006; p. 921-930.

4. Garud SS, Keilin S, Cai Q, Willingham FF. Diagnosis and management of Barrett's esophagus for the endoscopist. Therap Adv Gastroenterol. 2010;3:227-38. doi: $10.1177 / 1756283 \times 10365439$

5. Lippincott,Williams \& Wilkins Medical Management of Malignant Disease. In: Lippincot, Williams \& Wilkins The Washington Manual of Medical Therapeutics. $31^{\text {st }}$ edn. St. Louis, MI, 2004; p. 444.

6. Hu Y, Jones C, Gellersen O, Williams VA, Watson TJ, Peters JH. Pathogenesis of Barrett esophagus: deoxycholic acid upregulates goblet-specific gene MUC2 in concert with CDX2 in human esophageal cells. Arch Surg. 2007;142:540-4. doi: 10.1001/archsurg.142.6.540

7. McIntire MG, Soucy G, Vaughan TL, Shahsafaei A, Odze RD. MUC2 is a highly specific marker of goblet cell metaplasia in the distal esophagus and gastroesophageal junction. Am J Surg Pathol. 2011;35:1007-13. doi: 10.1097/PAS.0b013e318218940d

8. Szachnowicz S, Cecconello I, Ribeiro U, Iriya K, El Ibrahim R, Takeda FR, et al. Mucin pattern reflects the origin of the adenocarcinoma in Barrett's esophagus: a retrospective clinical and laboratorial study. World J Surg Oncol. 2009;7:27. doi: 10.1186/1477-7819-7-27

9. Rieder F, Biancani P, Harnett K, Yerian L, Falk GW. Inflammatory mediators in gastroesophageal reflux disease: impact on esophageal motility, fibrosis, and carcinogenesis. Am J Physiol Gastrointest Liver Physiol. 2010;298:G571- 81. doi: 10.1152/ ajpgi.00454.2009

10. Yuan J, Hernandez JC, Ratuapli SK, Ruff KC, De Petris G, Lam-Himlin DM, et al. Prevalence of buried Barrett's metaplasia in patients before and after radiofrequency ablation. Endoscopy. 2012;44:993-7. doi: 10.1055/s-0032-1325678

11. Moriyama N, Amano Y, MishimaY, Okita K, Takahashi Y, Yuki T, et al. What is the clinical significance of stromal angio- genesis in Barret's esophagus? J Gastroenterol Hepatol. 2008; 23 Suppl 2:S210-5.

doi: $10.1111 / \mathrm{j} .1440-1746.2008 .05440 . x$

12. Vascular endothelial growth factor [Internet]. [cited Nov 11, 2013]. Available at: http://en.wikipedia.org/wiki.

13. Wei Qu, Jin-Dong Fu, Fang Yang, Gong-Li Yang, Ya-Li Zhang, Xin-Ying Wang, et al. Clinical implications of PTEN and VEGF expression status, as well as microvessel density in esophageal squamous cell carcinoma. Oncol Lett. 2015;10: 1409-15. doi: 10.3892/ol.2015.3431

14. Maley CC. Multistage carcinogenesis in Barrett's esophagus. Cancer Lett. 2007;245(1-2):22-32. doi: https://doi.org/10.1016/j.canlet.2006.03.018

15. Steininger H, Pfofe DA, Müller H, Haag-Sunjic G, Fratianu V. Expression of CDX2 and MUC2 in Barrett's mucosa. Pathol Res Pract. 2005;201:573-7. doi: 10.1016/j.prp.2005.03.010

16. Ono H, Kondo H, Gotoda T, et al. Endoscopic mucosal resection for treatment of early gastric cancer. Gut. 2001;48:225-9. doi: http://dx.doi.org/10.1136/gut.48.2.225

17. Fiocca R, Villani L, Tenti P, Solcia E, Cornaggia M, Frigerio B, Capella C. Characterization of four main cell types in gastric cancer: foveolar, mucopeptic, intestinal columnar and goblet cells. A histopathologic, histochemical and ultrastructural study of "early" and "advanced" tumours. Pathol Res Pract. 1987;182:308-25. doi: 10.1016/S0344-0338(87)80066-3

18. Couvelard A, Paraf F, Gratio V, Scoazec JY, Hénin D, Degott $\mathrm{C}$, Fléjou JF. Angiogenesis in the neoplastic sequence of Barrett's oesophagus. Correlation with VEGF expression. J Pathol. 2000;192(1):14-8. doi: https://doi.org/10.1002/10969896(2000)9999:9999<::AID-PATH709>3.0.CO;2-F

19. Sharma VK, Crowell MD, Howden CW. Infection with H. pylori or CAGA $+H$. pylori is protective against Barrett's esophagus and esophageal adenocarcionoma: a metaanalysis. Gastroenterology. 2004;Suppl 2:A-87.

20. Khor TS, Alfaro EE, Ooi EM, Li Y, Srivastava A, Fujita H, et al. Divergent expression of MUC5AC, MUC6, MUC2, CD10, and CDX-2 in dysplasia and intramucosal adenocarcinomas with intestinal and foveolar morphology: is this evidence of distinct gastric and intestinal pathways to carcinogenesis in Barrett esophagus ? Am J Surg Pathol. 2012;36:331-42. doi: 10.1097/PAS.0b013e31823d08d6 


\section{Sažetak \\ IZRAŽENOST GLIKOPROTEINSKOG ANTITIJELA MUC2 \\ I VASKULARNOG ENDOTELNOG ČIMBENIKA RASTA (VEGF) U SLUZNICI BARRETTOVA JEDNJAKA}

\section{Ražov Radas}

Izražajnost glikoproteina mucina 2 (MUC2) i vaskularnog endotelnog faktora rasta (VEGF) u sluznici Barrettova jednjaka (BJ) može se dovesti u vezu s višim rizikom razvoja adenokarcinoma jednjaka. Studija je obuhvatila 36 bolesnika s dijagnozom BJ koja je potvrđena patohistološkom analizom nakon višestrukih biopsija ezofagogastričnog spoja. Izražajnost MUC2 i VEGF-a je prikazana imunohistokemijskom analizom. Otkrivena su četiri bolesnika u ranom stadiju adenokarcinoma (učinjena je totalna ezofagektomija) i 32 bolesnika s BJ, od kojih je petoro imalo indikaciju za argon plazma koagulaciju, jedan za endoskopsku resekciju sluznice, jedan za radiofrekventnu ablaciju, a 25 ih je liječeno inhibitorima protonske pumpe. Regresija BJ je zabilježena u 25 (69,44\%) bolesnika. Pozitivan nalaz MUC2 je karakterističan za vrčaste stanice u BJ, ali nije jedini biljeg. VEGF je pokazatelj angiogeneze u sluznici boelsnika s BJ i adenokarcinomom.

Ključne riječi: Barrettov jednjak; Mucin 2; Vaskularni endotelni faktor rasta; Protonska pumpa, inbibitori; Vrčaste stanice 